\title{
Glycoproteins in cystic fibrosis: a lectin binding study
}

\author{
S KARLSSON*, B GRIFFITHS, D M SWALLOW, D A HOPKINSON, AND \\ P G WALLIS $\dagger$
}

From the MRC Human Biochemical Genetics Unit, The Galton Laboratory, University College London, Wolfson House, 4 Stephenson Way, London NW1 2HE; and the Children's Hospital, 321 Sydenham Road, London SE26 5ER.

SUMmaRY Ten lectins have been used to detect glycoproteins, after SDS polyacrylamide gel electrophoresis and gel isoelectric focusing, in fibroblasts, red cell membranes, urine, and plasma of patients and obligate heterozygotes with cystic fibrosis. No disease specific changes were detected but considerable individual variation was observed, some of which was attributed to known genetic polymorphisms unrelated to cystic fibrosis.

There is abundant evidence to suggest that abnormalities of glycoproteins occur in patients with cystic fibrosis. ${ }^{1}$ Some of these features may be secondary effects, for example the changed density and solubility of glycoproteins in cystic fibrosis are probably attributable to increased $\mathrm{Ca}^{2+}$ concentration. ${ }^{23}$ However, differences in the sugar content might reflect a constitutional defect in glycosylation. Decreased fucose or increased sialic acid or both have been reported in duodenal fluid, pulmonary secretions, and rectal mucus, on the serum proteins which bind heparin, mucus glycopeptides from meconium, and decreased sialic acid and altered binding to lectins have been reported for serum $\alpha_{2}$-macroglobulin. ${ }^{14-6}$ Although there have been conflicting reports, these observations suggest a generalised defect in soluble glycoproteins possibly involving their processing. The possible role of the cell membrane in the pathogenesis of cystic fibrosis has led to a number of studies on the cell membrane glycoproteins and has provided some evidence for alterations of these components in fibroblasts, ${ }^{7-9}$ although several other studies failed to show differences. ${ }^{10-14}$ The purpose of this study was to investigate the glycan structure of soluble and membrane glycoproteins in cystic fibrosis patients, heterozygotes, and controls, using a wide variety of lectins to detect the glycoproteins after electrophoresis, employing the general technique originally described by Burridge ${ }^{15}$ and extending the study of Harris and Bramwell ${ }^{14}$ in which this technique was used to analyse fibroblast membrane glycopro-

\footnotetext{
${ }^{*}$ Present address: Department of Health and Human Services, National Institutes of Health, Bethesda, Maryland 20205, USA.

Received for publication 6 December 1983.

Accepted for publication 13 April 1984.
}

teins. Using this approach several tissues could be investigated, deficient or additional components could be identified, and abnormal glycan structures could, in principle, be pinpointed to particular molecules without previous purification. The material examined was plasma, red cell membranes, urine, and fibroblasts. These tissues were chosen because of their accessibility and also because considerable background information had already been acquired in this laboratory about the normal glycoprotein profiles in healthy subjects. Particular attention was paid to the newly described peanut lectin reactive urinary mucin (PUM) which shows genetically determined variation and occurs in urine, kidney, and lung. ${ }^{16}$ In selecting other lectins, attention was paid to the possibility of changes in fucose and sialic acid content. Thus the fucose binding lectin from Ulex europaeus (UEA-I) was included, and comparisons were made between the wheat germ agglutinin (WGA) binding profile (sialic acid and $\mathrm{N}$-acetylglucosamine) and that of succinylated wheat germ agglutinin (sucWGA) which binds $\mathrm{N}$-acetylglucosamine alone. Material treated with bacterial sialidase was also compared with untreated material.

A more limited survey of glycoproteins was also done using the same detection technique following isoelectric focusing in polyacrylamide gel with the purpose of detecting glycoproteins with altered charge characteristics.

\section{Materials and methods}

SDS POLYACRYLAMIDE ELECTROPHORESIS

Vertical sodium dodecyl sulphate (SDS) polyacrylamide gel electrophoresis (PAGE) was carried out as described previously. ${ }^{16}$ 
ISOELECTRIC FOCUSING

Isoelectric focusing (IF) of plasma samples was done using a $\mathrm{pH}$ gradient of 3.5 to 10 . Urine samples (concentrated approximately 20 times and made $5 \%$ in mercaptoethanol and $9.5 \mathrm{~mol} / \mathrm{l}$ in urea) were focused on gels containing $6 \mathrm{~mol} / \mathrm{l}$ urea. The gels $(0.2 \times 11 \times 25 \mathrm{~cm})$ were run for 2 hours adjusting the power pack to $25 \mathrm{~W}$ maximum with unlimited current and voltage, with cooling by water circulating at 8 to $10^{\circ} \mathrm{C}$.

\section{LECTIN STAINING}

Table 1 shows a list of the lectins used in the present study and their principal specificities. Lectin staining was carried out as described previously. ${ }^{16}$

\section{SAM P LES}

The 10 to 20 control samples tested from each type of tissue were from healthy young adults and children. On the IF gels fewer controls were tested but equal numbers of control and patient samples

TABLE 1 Lectins used in the present study, their abbreviations, and principal specificity.

\begin{tabular}{|c|c|c|}
\hline Lectin & Abbreviation & Principal specificity \\
\hline $\begin{array}{l}\text { Ulex europaeus agglutinin I } \\
\text { Helix pomatia agglutinin } \\
\text { Soybean agglutinin } \\
\text { Ricinus communis agglutinin I } \\
\text { Peanut agglutinin } \\
\text { Phaseolus vulgaris erythro- } \\
\text { glutinin } \\
\text { Wheat germ agglutinin } \\
\text { Succinylated wheat germ } \\
\text { agglutinin } \\
\text { Concanavalin A } \\
\text { Lens culinaris agglutinin }\end{array}$ & $\begin{array}{l}\text { UEA-I } \\
\text { HPA } \\
\text { SBA } \\
\text { RCA-I } \\
\text { PNA } \\
\text { PHA-E } \\
\text { WGA } \\
\text { sucWGA } \\
\text { CON A } \\
\text { LCA }\end{array}$ & $\begin{array}{l}\alpha-L-F u c \\
\alpha-D-G a l N A c \\
\alpha-D-G a l N A c \\
\beta-D-G a l \\
\beta-D-G a l(1 \rightarrow 3) D-G a l N A c \\
\beta-D-G a l(1 \rightarrow 4) D-G I c N A c \\
\beta-D-G i c N A c, \text { sialic acid } \\
\beta-D-G l c N A c \\
\alpha-D-M a n \\
\alpha-D-M a n\end{array}$ \\
\hline
\end{tabular}

were tested on each gel, matched as far as possible for age of sample and age of patient. Samples from cystic fibrosis patients (a total of 29 different patients, age range 2 to 22 ) and four obligate heterozygotes were obtained from Sydenham Children's Hospital, University College Hospital, and the Blood Bank, Reykjavik). The six patients whose fibroblasts were examined were six of the 17 studied previously by Harris and Bramwell. ${ }^{14}$

Urine samples were concentrated approximately 20 times using dialysis tubing and Aquacide (Calbiochem-Boehringer). Plasma samples from heparinised blood were diluted 10 times before analysis with SDS-PAGE but were diluted $1 / 3$ for analysis with isoelectric focusing. Red cell membranes were made using the technique of Fairbanks et $a l^{17}$ and the membranes stored up to 6 weeks at $-70^{\circ} \mathrm{C}$. Fibroblasts were grown in MEM (Flow Laboratories) containing $10 \%$ fetal calf serum. The cells were harvested using a rubber policeman and disrupted by freezing and thawing twice. The preparation was centrifuged at $100000 \mathrm{~g}$ to obtain a membrane-rich pellet.

SIALIDASE TREATMENT

Sialidase treatment was done by using Clostridium perfringens type VI (Sigma) sialidase in citrate phosphate buffer ( $\mathrm{pH} 5 \cdot 0)$ at a concentration of unit/ml. Two volumes of sample and one volume ơ⿱⺈⿻⺕亅八 the sialidase solution were incubated for one hour at $37^{\circ} \mathrm{C}$.

\section{Results}

PROTEIN PROFILES

SDS-PAGE was used to analyse urine from 10 cystic fibrosis patients, red cell membranes from three,

TABLE 2 Summary of material tested and results obtained by lectin analysis after electrophoresis.

\begin{tabular}{|c|c|c|c|c|c|c|c|c|c|c|c|c|c|c|c|}
\hline $\begin{array}{l}\text { Material } \\
\text { studied }\end{array}$ & $\begin{array}{l}\text { Sialidase } \\
\text { treatment }\end{array}$ & $\begin{array}{l}\text { No o } \\
\text { patier }\end{array}$ & $\begin{array}{l}\text { of } \\
\text { ents }\end{array}$ & $\begin{array}{l}\text { No of } \\
\text { hetero- } \\
\text { zygotes }\end{array}$ & $\begin{array}{l}\text { Electrophoretic } \\
\text { method }\end{array}$ & PHA-E & CONA & $W G A$ & $L C A$ & $R C A-I$ & sucWGA & PNA & $S B A$ & $H P A$ & UEA-I \\
\hline Urine & $\begin{array}{l}- \\
+1- \\
-\end{array}$ & $\left.\begin{array}{r}10 \\
5 \\
6\end{array}\right\}$ & 15 & & $\begin{array}{l}\text { SDS-PAGE } \\
\text { SDS-PAGE } \\
\text { IF }\end{array}$ & $\begin{array}{l}\text { nt } \\
+ \\
\text { nt }\end{array}$ & $\begin{array}{l}+ \\
+ \\
+\end{array}$ & $\begin{array}{l}+ \\
+ \\
+\end{array}$ & $\begin{array}{l}+ \\
\mathrm{nt} \\
+\end{array}$ & $\begin{array}{l}+ \\
+ \\
+\end{array}$ & $\begin{array}{l}+ \\
\text { nt } \\
(+)\end{array}$ & $\begin{array}{l}+ \\
+ \\
(+)\end{array}$ & $\begin{array}{l}(+) \\
\text { nt } \\
(+)\end{array}$ & $\begin{array}{l}\text { nt } \\
+ \\
+\end{array}$ & $\begin{array}{l}(+) \\
\text { nt } \\
\text { nt }\end{array}$ \\
\hline $\begin{array}{l}\text { Red cell } \\
\text { membranes }\end{array}$ & $+1-$ & 3 & & $4(+1 \mathrm{sib})$ & SDS-PAGE & + & + & + & $\mathrm{nt}$ & + & + & + & $(+)$ & + & + \\
\hline Plasma & $\begin{array}{l}+1- \\
- \\
+1- \\
+1- \\
+1-\end{array}$ & $\left.\begin{array}{l}2 \\
1 \\
3 \\
3 \\
3\end{array}\right\}$ & 6 & $\begin{array}{l}4(+1 \mathrm{sib}) \\
1\end{array}$ & $\begin{array}{l}\text { SDS-PAGE } \\
\text { SDS-PAGE } \\
\text { SDS-PAGE } \\
\text { IF } \\
\text { IF }\end{array}$ & $\begin{array}{c}+ \\
\mathrm{nt} \\
+ \\
+ \\
\mathrm{nt}\end{array}$ & $\begin{array}{l}+ \\
+ \\
\text { nt } \\
+ \\
\text { nt }\end{array}$ & $\begin{array}{l}+ \\
+ \\
+ \\
+ \\
\text { nt }\end{array}$ & $\begin{array}{l}\mathrm{nt} \\
\mathrm{nt} \\
\mathrm{nt} \\
\mathrm{nt} \\
\mathrm{nt}\end{array}$ & $\begin{array}{l}+ \\
\mathrm{nt} \\
+ \\
+ \\
+\end{array}$ & $\begin{array}{l}(+) \\
\text { nt } \\
\text { nt } \\
(+) \\
\text { nt }\end{array}$ & $\begin{array}{l}+ \\
\mathrm{nt} \\
+ \\
(+) \\
\mathrm{nt}\end{array}$ & $\begin{array}{l}(+) \\
\mathrm{nt} \\
\mathrm{nt} \\
(+) \\
\mathrm{nt}\end{array}$ & $\begin{array}{l}(+) \\
\text { nt } \\
n t \\
(+) \\
n t\end{array}$ & $\begin{array}{l}(+) \\
\mathrm{nt} \\
\mathrm{nt} \\
(+) \\
\mathrm{nt}\end{array}$ \\
\hline $\begin{array}{l}\text { Fibroblast } \\
\text { membranes }\end{array}$ & $\begin{array}{l}- \\
+ \\
+1-\end{array}$ & $\begin{array}{l}3 \\
3 \\
3\end{array}$ & 6 & & $\begin{array}{l}\text { SDS-PAGE } \\
\text { SDS-PAGE } \\
\text { SDS-PAGE }\end{array}$ & $\begin{array}{l}+ \\
\mathrm{nt} \\
\mathrm{nt}\end{array}$ & $\begin{array}{l}+ \\
\text { nt } \\
\text { nt }\end{array}$ & $\begin{array}{l}+ \\
\mathrm{nt} \\
+\end{array}$ & $\begin{array}{l}\mathrm{nt} \\
\mathrm{nt} \\
\mathrm{nt}\end{array}$ & $\begin{array}{l}+ \\
\mathrm{nt} \\
+\end{array}$ & $\begin{array}{l}(+) \\
(+) \\
\mathrm{nt}\end{array}$ & $\begin{array}{l}(+) \\
+ \\
n t\end{array}$ & $\begin{array}{l}(+) \\
(+) \\
\text { nt }\end{array}$ & $\begin{array}{l}(+) \\
(+) \\
\mathrm{nt}\end{array}$ & $\begin{array}{l}(+) \\
(+) \\
\text { nt }\end{array}$ \\
\hline
\end{tabular}

SDS-PAGE =sodium dodecyl sulphate polyacrylamide gel electrophoresis.

IF $=$ gel isoelectric focusing.

+ indicates glycoproteins detected.

$(+)$ indicates little or no glycoprotein detected in either patients or controls.

nt $=$ not tested. 


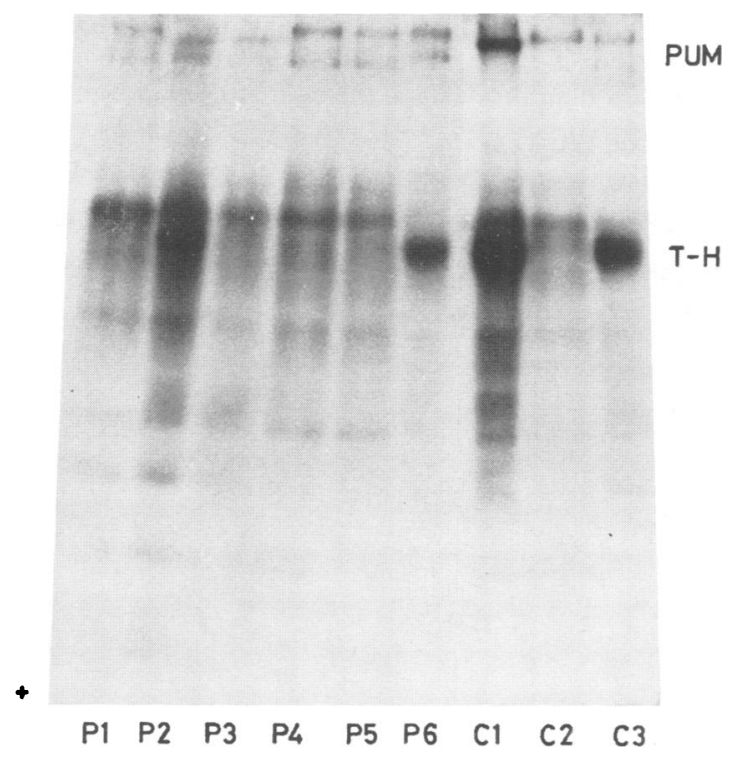

FIG 1 SDS gel stained with WGA showing urine specimens from six patients (P1-6) and three healthy controls (C1-3). For other abbreviations see text. plasma from two, and fibroblasts from six. Both sialidase treated and untreated red cell membrane preparations, plasma, and fibroblasts were examined. The gels were stained with Coomassie Brilliant Blue (CBB) and the protein profiles compared with those of control samples. We failed to detect any differences between cystic fibrosis patients and controls although several differences were observed within each group.

\section{GLYCOPROTEIN PROFILES}

The tissues examined and the lectins used are summarised in table 2 . In most cases material treated with bacterial sialidase was also examined as indicated in table 2 .

\section{GLYCOPROTEINS IN URINE}

Urine was analysed from 15 cystic fibrosis patients using SDS electrophoresis and from six patients using isoelectric focusing gels followed by staining with several lectins (table 2). There was considerable individual variation in the concentration of all or particular glycoproteins but these variations are not related to the disease. The PUM components ${ }^{16}$ were detected by PNA staining after SDS-PAGE of samples from 20 patients and they displayed a

\section{Acidic}

Basic

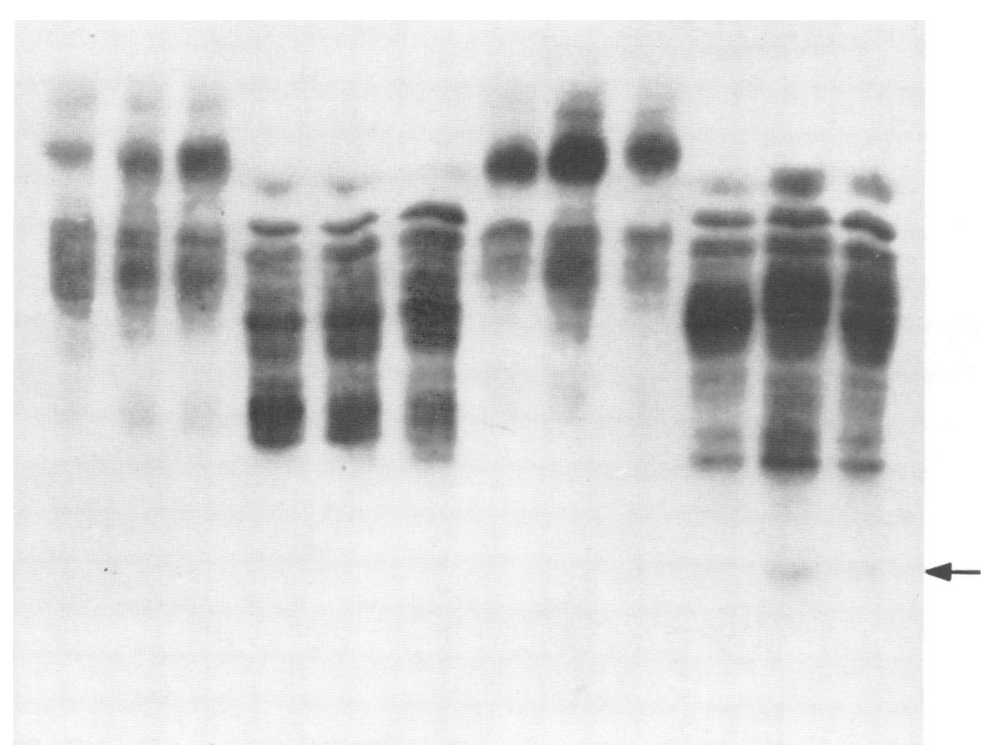

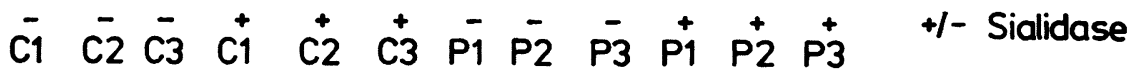

FIG 2 IF gel stained with RCA-I showing plasma samples (both sialidase treated and untreated) from three patients (PI-3) and three healthy controls $(C 1-3)$. 
random selection of the phenotypes detected in healthy subjects. With WGA this family of components was also detected (fig 1) together with many
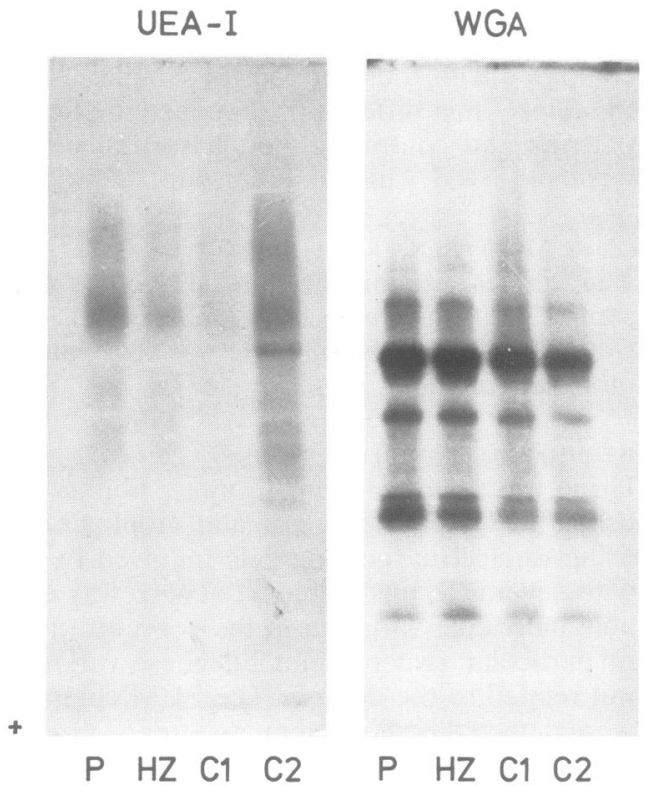

other components. The variation in the region designated $\mathrm{T}-\mathrm{H}$ is probably an artefact of the preparation method, since the centrifugation used to
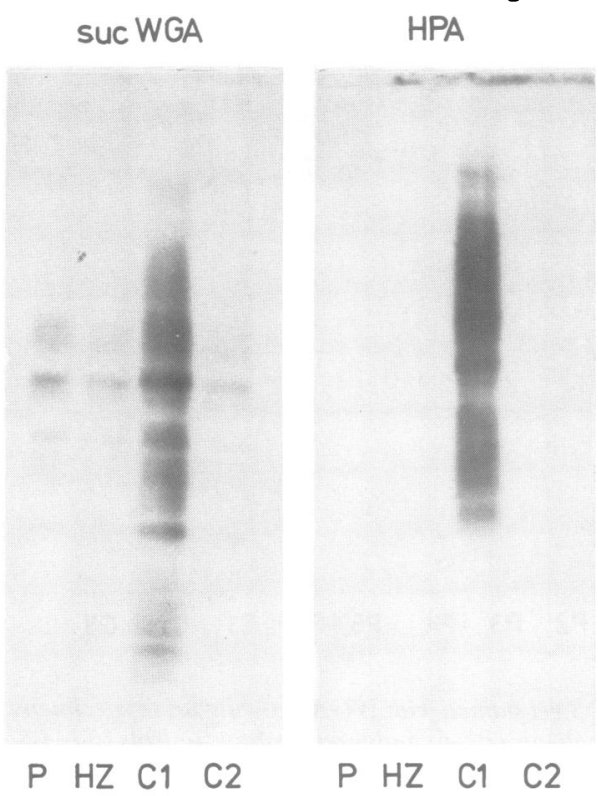

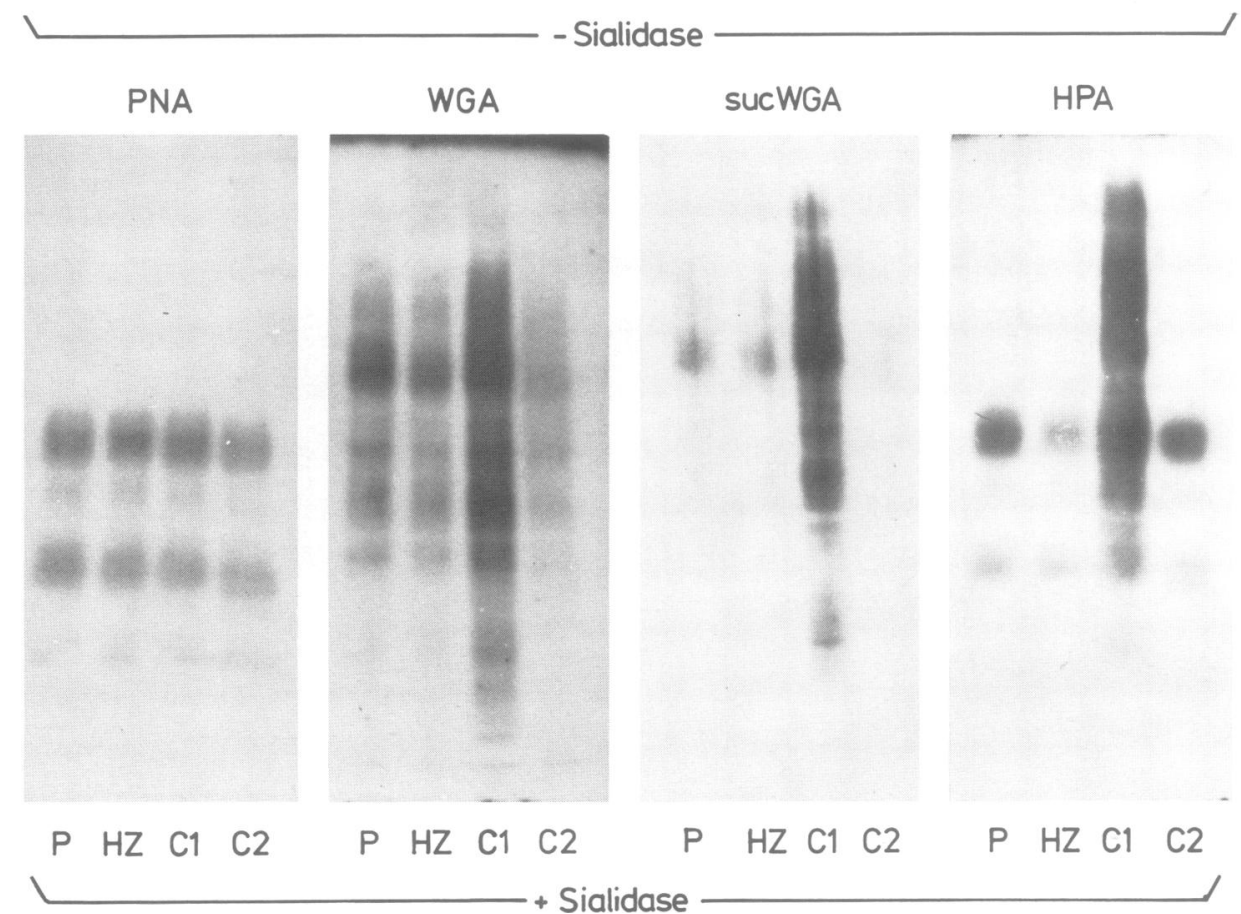

FIG 3 Pieces of SDS gels stained with various lectins (for abbreviations see table 1) showing red cell membrane preparations (with and/or without sialidase treatment) from one patient $(P)$, one heterozygote $(H Z)$, and two healthy controls $(C 1, C 2)$. Both the patient and heterozygote are blood group $B, C 1$ is $A_{l}$, and $C 2$ is $O$. 
clarify the samples removes variable amounts of the Tamm-Horsfall glycoprotein $(\mathrm{T}-\mathrm{H}) .^{18}$

GLYCOPROTEINS IN PLASMA

Plasma samples from six cystic fibrosis patients and four heterozygotes were analysed on SDS-PAGE and from six cystic fibrosis patients on isoelectric focusing gels (table 2). No reproducible differences between the patient and control samples were seen using either sialidase treated or untreated material, although in one IF experiment (fig 2) a component (indicated with an arrow) was detected with RCA-I in sialidase treated samples from three patients but not in the controls. However, a similar component was weakly visible in the control material after prolonged exposure ( 3 days) of the autoradiograph and, furthermore, was not visible on subsequent examination of the same material from the patients and controls or in several other cases.

\section{RED CELL MEMBRANE GLYCOPROTEINS}

There were no differences in glycoprotein profiles between the cystic fibrosis patients and the controls. However, some differences in staining were seen with the blood group reactive lectins, UEA-I and HPA, which appeared to be related to the different blood groups of the subjects analysed. HPA showed strong binding to the glycoproteins of $A_{1}$ subjects and UEA-I to the glycoproteins of type $\mathrm{O}$ subjects. These observations are compatible with those of Finne. ${ }^{19}$ Quite surprisingly sucWGA and WGA after sialidase treatment also distinguished the red cell membrane glycoproteins from persons of different blood groups. They bind strongly to those of blood group $A_{1}$ but weakly or not at all to those of blood groups $\mathrm{B}$ and $\mathrm{O}$. Fig 3 shows an example of the variety of patterns that may be observed with these lectins.

GLYCOPROTEINS IN FIBROBLAST MEMBRANES Membrane-rich extracts of fibroblasts, both treated and untreated with sialidase, from six cystic fibrosis patients were examined using up to nine different lectins after SDS-PAGE (table 2). None of the lectins used revealed any cystic fibrosis specific patterns, though the complexity varied considerably with the different lectins.

\section{Discussion}

SDS gel electrophoresis of the membrane associated proteins of the fibroblast and red cell failed to show any difference in protein and glycoprotein profile between cystic fibrosis patients and controls. The red cell membrane changes previously reported ${ }^{7}$ were detected using a very different electrophoretic system followed by the protein stain aniline blue black, but were in any case not present in all cystic fibrosis patients and were not specific for cystic fibrosis. Our failure to show any abnormality of fibroblast glycoproteins is at variance with the reports of abnormalities in the molar ratios of monosaccharides in the cell surface glycoproteins of cystic fibrosis fibroblasts, ${ }^{89}$ but consistent with the findings of Harris and Bramwell ${ }^{14}$ who used three lectins (CONA, WGA, and Lotus tetragonolobus) to detect glycoproteins after SDS gel electrophoresis.

Both SDS gel electrophoresis and isoelectric focusing were used to examine the 'soluble' glycoproteins of plasma and urine. No reproducible disease specific differences were detected. The RCA-I binding components detected in one experiment in plasma of three cystic fibrosis patients may have been an artefact or could conceivably correspond to one of the previously described cystic fibrosis factors present in plasma ${ }^{20}$ which are known to be somewhat labile.

Our inability to demonstrate any generalised or specific glycan changes in the cystic fibrosis material suggests that if the primary genetic defect is due to a mutation of a gene involved in processing glycoproteins (such as a glycosyltransferase or a glycosidase), the gene is not expressed in the tissues we have examined. It would be interesting to extend this type of study to examine less accessible material, such as pulmonary secretion, duodenal fluid, and sweat, which are more clearly associated with the pathology of this disease:

Although we have not demonstrated any disease specific changes in the course of this study, we have identified considerable person-to-person and sample-to-sample variation, some of which is attributable to known genetic polymorphisms, namely PUM and ABO. This variability illustrates some of the difficulties encountered in making a sensible interpretation of data derived from a screening approach to the analysis of a genetic disorder of unknown aetiology, and the value of conducting such a study against a background knowledge of the variation present in healthy persons.

We would like to thank the patients with cystic fibrosis and their parents for their cooperation; $\mathrm{Dr}$ J Shaw, University College Hospital, Dr H Bergsteinsson, National Hospital, Reykjavik, and Dr A Arnason, Blood Bank, Reykjavik for help in collecting samples from patients; The Cystic Fibrosis Research Trust, UK and the Blood Donors Association, Iceland for financial support (to SK); Dr Ann Harris for helpful discussions and access to the cell lines; and Tina Slade and Lynne West for help with cell culture. 


\section{References}

1 Alhadeff JA. Glycoproteins and cystic fibrosis: a review. Clin Genet 1978;14:189-201.

2 Gibson LE, Matthews WJ, Minihan PT, Patti JA. Relating mucus, calcium and sweat in a new concept of cystic fibrosis. Pediatrics 1971;48:695-710.

${ }^{3}$ Forstner JF, Forstner GG. Effects of calcium on intestinal mucin: implications for cystic fibrosis. Pediatr Res 1976;10:609 13.

4 Ben-Yoseph Y, De Franco CL, Nadler HL. Decreased sialic acid and altered binding to lectins of purified $\alpha_{2}$-macroglobulin from patients with cystic fibrosis. Clin Chim Acta 1979;99:31-5.

5 Shapira E, Menendez R. Increased binding of concanavalin A to $\alpha_{2}$-macroglobulin, IgM and IgG from cystic fibrosis plasma. Biochem Biophys Res Commun 1980;93:50-6.

6 Ben-Yoseph Y, De Franco CL, Nadler H. The metabolism of sialic acid in cystic fibrosis. Pediatr Res 1981;15:839-42.

${ }^{7}$ Fitzpatrick DF, Landon RJ, James V. Serum binding of calcium and the red cell membrane in cystic fibrosis. Nature 1972;235:173-4.

8 Scanlin TF, Glick MC. Differences in monosaccharide composition of membrane glycopeptides from cystic fibrosis and control skin fibroblasts. Pediatr Res 1977;11:463.

9 Scanlin TF, Glick MC. Surface membranes from cystic fibrosis fibroblasts. Proc 7th Int CF Cong, Paris, 1976. Paris: Association Internationale de la Lutte contre le Mucoviscidose, 1978: 44-52.

${ }^{10}$ Fletcher DS, Lin TY. Incorporation of L-leucine and Dglucosamine in skin fibroblasts derived from cystic fibrosis and normal individuals. Clin Chim Acta 1973;44:5-19.

1 Changus JE, Quissell DO, Sukup MR, Pitot HC. Studies on the synthesis of plasma membrane proteins of fibroblasts from patients with cystic fibrosis. Am J Pathol 1975;80:317-28.
12 Baig MM, Certorelli JJ, Roberts RM. Plasma membrane components of skin fibroblasts from normal individuals and patients with cystic fibrosis. J Pediatr 1975;86:72-6.

${ }^{13}$ Owen E. Surface labelling of human skin fibroblasts of healthy and cystic fibrosis subjects. $J$ Mol Med 1978;3:203-11.

14 Harris A, Bramwell ME. Cystic fibrosis: a detailed analysis of fibroblast membrane glycoproteins. Clin Chim Acta $\overline{\bar{c}}$ 1983;128:41-51.

15 Burridge K. Changes in cellular glycoproteins after transformation: identification of specific glycoproteins and antigens in sodium dodecyl sulfate gels. Proc Natl Acad Sci USA C 1976;73:4457-61.

16 Karlsson S, Swallow DM, Griffiths B, et al. A genetic polymorphism of human urinary mucin. Ann Hum Genet 1983;47:263-9.

${ }^{17}$ Fairbanks G, Steck TL, Wallach DFH. Electrophoretic analysis of the major polypeptides of the human erythrocyte membrane. Biochemistry 1971;10:2606-17.

18 Tamm I, Horsfall FL. Characterization and separation of an inhibitor of viral hemagglutination present in urine. Proc Soc ? Exp Biol Med 1950;74:108-14.

19 Finne J. Identification of the blood group $\mathrm{ABH}$-active gly- $\rightarrow$ coprotein components of human erythrocyte membranes. Eur $J \subseteq$ Biochem 1980;104:181-9.

${ }^{20}$ Bullock S, Hayward C, Manson J, Brock DJH, Raeburn JA. Quantitative immunoassays for diagnosis and carrier detection in cystic fibrosis. Clin Genet 1982;21:336-41.

Correspondence and requests for reprints to $\mathrm{Dr}$ D M Swallow, MRC Human Biochemical Genetics Unit, The Galton Laboratory, University College $\overrightarrow{0}$ London, Wolfson House, 4 Stephenson Way, Loํㅛㅇ don NW1 2HE. 